\title{
Two Oils, One Evil: an Appraisal of Contemporary Dilemma of the Indigenous Population of Nigeria's Oil-Delta Communities, 1956-2019
}

\author{
Victor O. Ukaogo ${ }^{1} \&$ Nwakuya Cecilia Ogechi ${ }^{2}$ \\ ${ }^{1}$ Department of History \& International Studies, University of Nigeria, Nsukka, Enugu \\ State, Nigeria. Email: victor.ukaogo@unn.edu.ng \\ ${ }^{2}$ Careers Unit (Registry Department), University of Nigeria, Nsukka, Nigeria. \\ Email: Ogenwakuyah@yahoo.com
}

\begin{abstract}
This study examines the processes of economic transition and the corresponding impact on the Niger-Delta communities. It argues that the region has witnessed several epochs of economic transition; all of which came with damning consequences. While the major focus of the study is the change from palm oil to crude oil (two oils), the study explores the curious linkage between economic transitions, contemporary poverty and environmental violence in the region (one evil). The integration of the region into the vortex of oil globalization has paradoxically and inversely increased the poverty amongst the rural poor. The study argues that while the 'oily debacle' yield endless violence against the indigenous population, issues of environmental governance exacerbates. This is evidenced in the government's militarized mediation strategies that worsen the prospects of peace in the enclave. Typical of 'resource curse' philosophy, the wealth from crude oil that should improve the lot of the rural poor has directly shut them out of the expected benefits of oil extraction. The study investigates and avers that the unholy alliance between the State and global capital is a challenge and concludes that capitalist exploitation of the region on account of crude oil explains the contemporary dilemma of the indigenous population.
\end{abstract}

Keywords: Niger-Delta; Globalization; Foreign Interest; Environmental Governance; Resource curse;

Environmental security; Capitalist exploitation

\section{Introduction}

The two oils of palm oil and crude oil constitute products of pain for the population of NigerDelta. Both can be referred to as 'oils of evil' given the pain they have brought upon the people. From the era of palm oil to crude oil, the Niger-Delta has contributed to world energy and industrial growth but has paradoxically remained in the doldrums and fringes of development on account of the convergence of Nigeria's political and economic vices in the region. It is believed to be the poverty capital of Nigeria; probably explaining the recurring incidents of violence and abuse in the region ostensibly from the contestations related to wealth and power. Complaints abound in the land; and from imperial humiliation through colonial exploitation, the region has journeyed to the present crisis of oily debacle that has pitched the people not only against foreigners as was the case in the past but against their own government in the present. All these emanate from conflicts and struggles over the appropriation and control of environmental resources like palm and crude oil. The strategic nature of the Niger-Delta, particularly in the context of global energy security confers on the region an important status in contemporary

(C) AesthetixMS 2020. This Open Access article is published under a Creative Commons Attribution Non-Commercial 4.o International License (http://creativecommons.org/licenses/by-nc/4.o/), which permits non-commercial re-use, distribution, and reproduction in any medium, provided the original work is properly cited. For citation use the DOI. For commercial re-use, please contact editor@rupkatha.com. 
world diplomacy and inter-state relations. Crude oil has played and will continue to play significant role in Nigeria's foreign relations as Nigeria conducted her foreign relations especially in the 1970 and 1980 s with crude oil as a weapon. It is within this context that the concerns over environmental security, pollution, regional security, global energy crisis and governance become instructive and pivotal in this study. The way the prevailing economic transition has impacted on the Niger-Delta would seem to have oscillated between docility, militancy and criminality. This may have arisen from what Robert Bullard (1999) and David Friedman (1998) referred to as 'environmental racism' evidenced in the large scale neglect, alienation and marginalization of the region.

The second collapse of what later became Nigeria especially the coastal territories and highlights the economic transition from human trade to legitimate commerce. It amplifies the transition within transition (Ukaogo, 2008:344) that was evident in the switch from palm oil to crude oil along with its consequences. What ordinarily appeared a harmless economic enterprise by the British slowly but methodically ensured not just the forceful integration of the geographical space into the curious orbit of international finance capital but turned Nigeria into a capitalist playground footnoted by exploitation without conscience. The early transition that yielded the abolition of slave trade did not create any vacuum in the commercial relations between West Africa (Nigeria) and Britain; rather, the old traffic had a more rigorous successor in the palm oil trade' (Ukaogo, 2007). The associated rigor translated into economic boom for the metropolis for which 'we may argue, that just as Jenne or Timbuktu rose in response to trans Saharan trade, so did the coastal cities of the Niger-Delta.....emerged as a response to maritime commerce' (Ukaogo,2007:103). This was made possible by the rise of British Consular power in the Bights of Benin and Biafra as a necessary method of not only ensuring the British economic, political dominance and hegemony in the region but a process of integrating the region into global finance capital as indicated earlier. The step indicating the plot to exploit Nigeria was the termination of the charter which conveniently enabled the British to take over the commanding economic and political heights of Nigeria and the use of marketing boards as a spring board of determining prices of local produce in the overall scheme to entrench foreign interests in the region. The nineteenth century brought about significant and notable changes in the Niger- Delta (Falola, 1991:9) namely the abolition of slave trade and the transition from slave economy to forest products. These changes were entirely economic but yielded political repercussions which subverted the sovereignty and suzerainty of the leadership of ethnic nationalities (Latham, 1973:32; Ryder, 1969). This was central to the condition of exploitation that defines relations between Nigeria and the outside world up to the $21^{\text {st }}$ century. The popular aphorism that history has a way of repeating itself cannot be more affirmed by the developments in the Niger Delta region for centuries now. From the era of subsistence economy, the region has struggled with one form of challenge to another manifesting 'material inequality' and 'unequal control' between the resource bearing communities and foreigners have placed the region on a precarious situation aptly captured by Naanen (2001) to the effect:

that the resources of the Niger Delta were expropriated, first, by the British Crown by right of conquest, symbolized by imperialism and colonialism, then, passed on to the successor Nigerian-state.

\section{Economic Transition in the Niger-Delta: background to Exploitation}

Trade in the Niger-Delta from as late as 1800 to 1955 involved two rather broad 'commodities', namely human trade and forest products. This is in spite of the fact that by 1807 , the British 
Parliament had outlawed slave trade but the trade continued more discreetly by way of domestic slavery. For both epochs, foreign interests predominated in the region and often pitched the natives against each other or against foreigners. By the early $19^{\text {th }}$ century, legitimate commerce had stabilized and several individuals and interests had been drawn inseparably into the vortex of a new but aggressive quest for money that singly altered the history of the region. The slave economy continued with the resistance of the slavers which yielded the enduring indication of domination and oppression in the relations between the indigenous populations and foreign traders. The continued pressure by anti-abolitionists forcefully compelled the traders to accept the new trade in forest products but not without a scheme to maintain the stranglehold on the local economy that immediately began to blossom. The anticipated prosperity from legitimate commerce encouraged all the parties in the Niger-Delta to reposition themselves for the benefits associated to the transition and switch to palm oil.

\section{Palm Oil and the Entrenchment of British Imperial Designs}

The transition to palm oil trade revealed that it differed significantly from the slave trade. The transition threw up worrisome imperial designs of the British. Slave trade thrived on violence as the tiny powerful cabal of slavers 'terrorized and preyed upon the weak and defenseless' majority. However, legitimate commerce thrives on and is boosted by law and order although this became questionable later as the British predators applied all strategies to alienate and marginalize local tradesmen, a situation that resulted to conflicts and bloodshed. European scheme to permanently under-develop and exploit Nigeria did not commence with the palm oil trade as championed by the British in Nigeria. Its foundation was carefully and craftily laid at the twilight of the slave trade. There is no doubt that the transition to legitimate trade particularly in palm oil was clearly inevitable (Cited in Akinsanya \& Akindele , 2018: 270). Flint noted that:

The anti-slave-trade movement in Europe was itself... a product of growing European industrial capitalism... That the anti-slave movement was able to crush the vested opposition of powerful trading interests in Liverpool, Bristol, London and the British West Indies was partly the result of new economic attitudes towards West Africa which were growing in Britain (Akinsanya \& Akindele, 2018:270).

The obvious preference for legitimate commerce was in large measure occasioned by British gluttonous quest for African forest products such as dyes, gums, palm oil, palm kernels oil, groundnuts and benni-seed amongst others. There is therefore a corresponding meaning that the abolition was not fueled by humanitarian instincts and consideration but borne out of curious imperial designs of exploitation. A projection that the demand for African forest produce may outweigh that of human cargo based on enlightened commercial self interest encouraged the support for abolition. It was in consideration to the above that a Eurocentric scholar gleefully observed that:

African rulers or entrepreneurs who could organize a large supply of groundnuts or palm produce could obtain a good market for them. Slaves provided the necessary labour force. The European philanthropists, who hoped that trade in vegetable produce would drive out the slave trade, were inaugurating a new kind of demand for slave labour with a slave trade to feed it. Driven from the Atlantic, the slave trade went on within Africa to recruit labour to grow produce for new European markets (Fyfe cited in Ajayi, 1974:30-36). 
By all of this, the transition away from slave trade impoverished African traders with the concerted European penetration into the hinterland; an initiative that made Africans mere middlemen and hustlers to big European supercargoes. By subordinating African traders through coercive conversion to 'hustlers' and the rapidly expanding trade in tropical produce, the economies of African satellite states became forcefully integrated into global finance capital. This forceful integration tied African economies to those of Europe and thus laid a suitable bed for the rape of the continent as the British 'were determined to improve their own profit prospects and expand their export trade portfolio' (Asuk, 2011:9). It is true that the palm oil trade was an integral part of the slave trade and with it the rise and emergence of indigenous accumulators and prosperous entrepreneurs in the Niger Delta (Latham cited in Pasch \& Jones, 1986). This indigenous merchant class was fiercely independent and began to engage in export trade in the task of making more profits and sidelining the European merchants. The opulence and audacity of the indigenous entrepreneurs grew by the day and prompted attitudes of overreach as evidenced by King Eyo of Old Calabar whose attempt to ship his commodities direct to Europe involved his leasing a full vessel in 1857 to ship commodities to England (Dike, 1956:38) but was resisted when he was forced to pen an undertaking against direct sales or export to England. As if this was not enough, King Nana of Itshekiri, King Jaja of Opobo, and Dappa Pepple of Bonny; the foremost and leading African entrepreneurs nursed greater ideas of exporting palm oil to Europe (Rotimi \&Ogen, 2008), the aftermath of which created bad blood between them and European traders. These traders were thereafter seen as African dissenters and paid the ultimate price as evidenced in the 'de-stooling' and exiling of these 'trade obstructionists' of the Delta.

\section{Transition within Transition: Crude Oil and Descent to Full Blown Exploitation}

The deliberate ousting of the slave economy in preference to legitimate commerce marked a single transition from one economic epoch to another; the transition from palm oil to crude oil manifested as a transition within a transition. In clearer perspective, within the underbelly of legitimate trade rests the palm oil and the crude oil periods of economic transition. It is this movement from one transition to the other within the broader economic unit of legitimate trade that is referred to as transition within transition. The transition from palm oil to crude oil occurred within a period of fifty years. At the dawn of 1900, commercial slavery could be said to have given way to legitimate commerce in palm oil and other forest products. All stakeholders participated in the booming trade ostensibly to make profit. Industrial Europe was at peace with itself as profits from their merchants poured in like torrents. Much effort and devotion was channeled to expanding the frontiers and horizon of profit. Indeed, Europe began the search for more articles of legitimate commerce to further boost their economy at home especially within the context of fine-tuning the on-going industrialization project. Perhaps, it could be successfully argued that the second phase of the intensification of European industrialization began with the ceaseless search and exploitation for hydrocarbons.

The discovery of crude oil in 1956 and the interest and outcomes that followed it was a cruel reminder of the palm oil era. In the trade and politics that prevailed in the preceding century, foreign interests dominated especially the Liverpool traders who were spurred on by the consuls and their gunboats that reigned unchallenged. Then, just as it is now, the foreign traders ripped off the Niger- Delta and their middlemen traders. The rip-off strategy of the supercargoes was built into the exchange system. For in the absence of a standardized medium of exchange, the supercargoes gave the African traders worthless goods and carted home African tropical produce. Indeed, this much was captured by Dike most aptly thus: 
White supercargoes had managed to convince Africans that, articles of clothing such as old soldier jackets and cocked hats bought at little cost at Monmouth Street, were a fair exchange for their raw material (Ukaogo, 2009:44-53).

The unequal exchange of the period was a pointer of things to come. European supercargoes gave African traders worthless goods in exchange for palm oil which became the evidence that exchange governance in the crude oil era was most pitiable. This was probably what Okonta and Douglas meant when they averred that 'the plunder of the Niger-Delta has turned full circle, crude Oil has taken the place of Palm Oil but the dramatis personae are the same' (Okonta \& Douglas, 2001:14). The 'full circle' is a euphemism for a re-armament of sort to emasculate the oil bearing communities. Without fears of 'not going to heaven', the exploiters from Europe were clearly in sync with the objective of pursuing and expanding European industrial capitalism.

All was possible because the structure of Nigeria's oil industry has been made in favor of foreign domination and exploitation. First, the legal leverage given to Shell D'Arcy now Shell in 1938" to prospect for and exploit oil over the main land of the country (Obi, 1999:45a). The size of the area at about 367,000 square miles (Obi, 1999b:3) was more of a blank cheque which essentially transferred the economic fortunes of the state to a foreign conglomerate from colonial times to date. To further open up the economy for further foreign domination, Shell's area of influence was reduced to 16,000 square miles in 1957 but this was to ensure the accommodation of other oil firms (Obi, 1999a:45). This led to the admission of other firms like Texaco, Elf, Chevron (formerly Gulf Oil), Mobil etc into the oil trade (Obi, 1999:27a). However, lacking in capital, technology and skilled personnel, the state could not control production. The peripheral role of the state is only visible in the Joint Venture Agreement with oil firms in the country. This agreement merely made Nigeria a "monk without hood" and thus the oil conglomerates especially Shell remained quite dominant in the economy. Table 1 below is quite illustrative of the dominance of foreign interests in the Nigerian oil sector with its massive consequences for the generality of the people.

Table 1: Contribution of Oil to the Federal Purse (1957-1992)

\begin{tabular}{|l|l|l|l|l|l|}
\hline Year & $\begin{array}{l}\text { Oil } \\
\text { Revenue }\end{array}$ & Year & $\begin{array}{l}\text { Oil } \\
\text { Revenue }\end{array}$ & Year & $\begin{array}{l}\text { Oil } \\
\text { Revenue }\end{array}$ \\
\hline $1958-1959$ & 0.1 & $1969-1970$ & 17.2 & 1980 & 83.8 \\
\hline $1959-1960$ & 1.0 & $1970-1971$ & 26.0 & 1981 & 75.1 \\
\hline $1960-1961$ & 1.1 & $1971-1972$ & 52.5 & 1982 & 71.8 \\
\hline $1961-1962$ & 7.4 & $1972-1973$ & 41.5 & 1983 & 69.1 \\
\hline $1962-1963$ & $7 \cdot 3$ & $1973-1974$ & 71.4 & 1984 & 77.2 \\
\hline $1963-1964$ & 4.0 & $1974-1975$ & 80.8 & 1985 & 77.8 \\
\hline $1964-1965$ & $5 \cdot 3$ & $1975-1976$ & 87.0 & 1986 & 65.8 \\
\hline $1965-1966$ & 9.1 & $1976-1977$ & 84.0 & 1987 & 76.0 \\
\hline $1966-1967$ & $13 \cdot 3$ & $1977-1978$ & 84.1 & 1988 & 78.2 \\
\hline $1967-1968$ & 14.0 & $1978-1979$ & 80.0 & 1989 & 82.3 \\
\hline $1968-1969$ & 9.9 & $1979-1980$ & 83.6 & 1990 & 79.8 \\
\hline & & & & 1991 & 78.1 \\
\cline { 3 - 5 } & & & & 1992 & 82.0 \\
\hline
\end{tabular}


It does appear from all indications that the state is satisfied by this arrangement wherein foreign capital dominates the economy. Merely collecting rents, royalties (Ihonvbere, 1998) and excluded completely from actual oil production (Graf, 1988) the country is trapped in this appalling descriptive definition. The oil-state nexus (Obi, 1999a:3) sharpens the domineering role of foreigners in the state economy and reveals in sharper focus the conspiracy within the ruling elites that are even fragmented due to interest, alliances and realignments. The fragmentation of the ruling class does not dull their sense of purpose as in the complete milking of the Nigerian "Cow" and the alienation and marginalization of the "tenders of the cow". This fragmentation is most visible in numerous outcomes and character of state intervention in conflicts that pointedly reflects "the balance of forces contending for supremacy within this contested site."The "privatization" of Nigeria is therefore the handiwork of the fragmented and fractured elite with their allies from the outside. All these have expectedly bred discontent in the Delta region and remain a major factor in the deepening crisis in the region. Elsewhere, 1 argued (Ukaogo, 2000:192) that transnational business (foreign interests) ethics in collaboration with state policies are central to the crisis in the Delta region. As the crisis is manifestly cocooned in the envelope of "the unwholesome exploration and exploitation of oil", Joseph Campbell admits that 'company and their leaders primarily cater for individuals and national greed and bottom line profitability, often devaluing life itself (Campbell, 2020).

The oil firms through unequal partnership and dependent relations feed the Nigerian State with rents. This is shamefacedly accomplished in three interrelated ways and methods namely; the joint venture agreement, production-sharing contract and risk sharing contract (ERAction, 2004). In line with the alliance entered into with the oil firms, the state deploys all her instruments of coercion to providing access and protection to the firms in an undeclared war against the oil-bearing communities that are daily assailed by the hazards of environmental degradation. While the natives seethe in anger, the state-oil alliance busies itself with the search for more oil instead of addressing the bottled up anger (Obi, 1997:2) in the localities. This partnership has been responsible for the entrenched stranglehold of foreign capital on the Niger Delta along with the awesome consequences of the unequal fraternal ties. Indeed Obi put it most succinctly when he observed that:

At stake is the right of oil communities to save their environment against state-oil multinational extraction and degradation. Oil degradation and pollution strike at the heart of the survival of oil producing communities (Obi, 1997:2).

The greatest pain however remain that as agents of foreign capital, these firms take pleasure in violating all known legal environmental regimes or provisions including international practices thus sacrificing the ecology and environment of a people on the altar of profit and the market place. Moreover, Brooks opined that 'very little is ploughed into the communities that bear the heavy environmental costs of oil production (Brooks, 1999:15). This is verifiable for in the views of Rowell 'the money spent on community assistance in the past twenty-five years is just 0.000007 percent of the value of oil extracted' (Rowell, 1994). All these underscore the crisis of environmental conflict and the imperative for security. Thus environmental security in the views of Obi:

deals with the containment of a wide range of 'threats' or contradictions emanating from the interactions between human beings and nature... in the form of the extraction of natural resources or their transformation into foods, goods and services for livelihood purposes or for profit (Obi, 2000:50). 
While the first strand of the thought above highlights the interest of the privileged class that have power, access and control of the ecosystem and marginalizes those who do not have the same, the second strand that is of global relevance goes beyond the statist boundary and impinges clearly on the Niger Delta communities and their communities. In this direction, a scholar held that environmental security is a:

transnational idea the core of which holds that environmental degradation and depletion, largely human-induced pose fundamental threats to the physical security of the individual, groups, societies, states, ecosystems and the international system (Dalbelko \& Dalbelko cited in Obi, 2000:50).

Issues of oil extraction and transformation are essentially anchored on access, control, ownership and power and are related to political economy and security. In the Niger Delta, it is possible to identify a three stage coach or a tripartite level of conflict namely local, national and international all of which have thrown up the different actors and stakes involved in the titanic struggle surrounding oil production. Oil production is the most important economic activity in Nigeria and has impacted negatively on the Niger Delta communities, devastated their physical environment and bio-diversity (Aworawo, 2000:89), spawned conflicts and insecurity in the region especially the unending schism between oil-bearing communities and transnational oil firms. This schism that is deep rooted encourages a recurring thought i.e. if foreigners and other Nigerians benefit from the oil wealth of the Niger Delta, then the lot of the local population could be better (Ukaogo,2000:67). From all that we have said, exploitation evidenced in the unequal and iniquitous disparity in the benefits of oil, manifests on two levels; the first on the immediate communities from whose subsoil oil is extracted and secondly on the wider Nigerian state that lacks the technology of oil production and thus surrenders the processes and procedures of oil production to foreigners and in a 'big brother' display of benevolence, pays rents of pittances into the federal purse while in reality appropriating for itself and the home governments the largest proportion of oil benefits from Nigeria.

\section{Conclusion}

The study has shown deep manifestations of exploitation spawn by the two oils that have yielded one evil that challenge the indigenous population. The State-oil conspiratorial alliance against the people explains the violence that pervades the Niger-Delta enclave. The raging storm of exploitation in the Niger Delta and by extension Nigeria is not a recent development; it has rather received more violent impetus by the state-oil alliance. The alliance between the local comprador bourgeoisie class and foreign capital has ensured the continuation of the fleecing of the people kick started centuries ago but cemented in modern era by sundry methods of deception, plunder, carrot and stick strategies deployed to divide the people. It has become even more entrenched and pervasive with the level of abject poverty, violence, criminality, deprivation, and devastation in the land. The primitive accumulation of wealth by members of the alliance has stunted local economic growth while the capitalist transformation of the fleeced territory remained a forlorn hope. And as long as the conditions remain conducive for limitless capital accumulation and expropriation, so has imperial exploitation endured. The inability of Nigeria's post colonial government with its despotic power to check foreign excesses in the suppression of economic growth and the promotion and globalization of poverty and the rise of criminality, the future of Nigeria is bleak. The dialectics of the crude oil economy along with the rising quest for resource control in the Niger Delta amplifies the trajectories of the region and probably justifies the resort to violence, criminality and the promotion of unsound ideologies of resistance and self determination. 


\section{References}

Andrew Rowell. 1994. Shell Shocked: The Environmental and Social Costs of Living with Shell in Nigeria. Amsterdam: Greenpeace International, 1994.

Asuk, O. C. 2011. Two Oils, Same Phenomena: Historicizing Exclusion, Poverty and Contemporary Violence in the Niger Delta, African Research Review, Vol. 5 (2), Serial No. 19. 9

Ajayi, J.F.A. 1965. Christian Missions in Nigeria 1841-1891: the Making of New Elite. London: Longman. 42.

Akinsanya, Adeoye A. \& Akindele, Rafiu A. 2018. 'Legitimate Trade, Annexation and Cession of Lagos and International Law., Journal of Management and Social Sciences, Vol. 7(1), 270.

Aworawo, David. 2000. 'The Impact of Environmental Degradation in the Rural Areas of the Niger Delta" in Osuntokun, A. ed. The Environmental Problems of the Niger Delta, Lagos: Friedrich Ebert Foundation. 89.

Brooks, G. 1999. 'Slick Alliance-Shell's Nigerian Fields produce few Benefit for Region's Villages”, The Wall Street Journal, May 6, 5 .

Campbell Joseph. 2020. 'Global Economics and the Environment';http: earthrenewal.org $\mid$ globaleconomics,(Accessed on the April 16.

David, Friedman. 1998. The ‘Environmental Racism’ Hoax. American Enterprise Nov/December.

Bullard, Robert. 1999. 'Dismantling Environmental Racism in the USA', Local Environment,Vol. 4, No. 1,

Dike, K.O. 1956. Trade and Politics in the Niger-Delta, 1830- 1885 (Oxford: Clarendon press, 32.

ERAction. 2004. April-June, 18.

Falola, Toyin. 1991. The Story of Nigeria, (London: Greenwood Press. 19.

Falola, Toyin. 1999. The History of Nigeria, (London: Greenwood Press. 46.

Flint, J.196o. Sir George Goldie and the Making of Nigeria. Oxford: Oxford University, Press. 187-215.

Graf, W. 1988. The Nigerian State: Political Economy, State, Class and Political System in Post Colonial Era (London: James Carrey.

.Ihonvbere Julius and T. Shaw. (1998). 'Towards a Political Economy of Nigeria: Petroleum and Politics at the Semi Periphery, Aldershot, Avbury.

Latham, A.J.H.(1973). Old Calabar, 1600-1891: The Impact of the International Economy upon a Traditional Society. Oxford; Clarendon Press. 32.

Latham, A. J.(1986). 'Palm Oil Exports from Calabar, 1812-1887, With a Note on Price Formation' in Liesegang, H., H. Pasch and A. Jones, (eds), Figuring African Trade: Proceedings of the Symposium on the Quantification and Structure of the Import and Export and Long-Distance Trade in Africa, 180o1912. Berlin: D. Reinner.

Naanen, B.(2001). 'Bala Usman, History and the Niger Delta'. The Channel online, September.

Obi, Cyril. (1997). 'Oil Environment, Conflicts and National Security in Nigeria: Ramifications of the Ecology-Security Nexus for Sub- regional Peace' ACDIS Occasional Paper, University of Illinois at Urbana-Champagne, January. 2.

Obi, Cyril. (1999a). 'The Crisis of Environmental Governance in the Niger-Delta 1985-1996', Occasional papers, (AAPS), Vol. 3, no 3, 3.

Obi, Cyril. (1999b). 'Globalization and Environmental Conflict in Africa', Africa Journal of Political Science, Vol.4, No. 1, 45 . 
9 | Two Oils, One Evil: an Appraisal of Contemporary Dilemma of the Indigenous Population of Nigeria's Oil-Delta Communities, 1956-2019

Obi, Cyril. (2000). 'Globalized Images of Environmental Security in Africa', Review of African Political Economy, No.83, ROAPE Publications. 50.

Okonta Ike and Oronto Douglas. (2001). Where Vultures Feast. Benin: ERA/FoEN.14.

Ryder, Alan. (1969). Benin and the Europeans 1485-1895. London: Longman Publishers 32.

Rotimi, K. and Olukoya Ogen. (2008). 'Jaja and Nana in the Niger Delta Region of Nigeria: ProtoNationalists or Emergent Capitalists', Journal of Pan African Studies, vol. 2, no. 7, December.

Ukaogo, Victor. (200o). 'Transnational Business Ethics, Government Policies and the Crisis of Pollution and Underdevelopment in the Niger Delta' In Osuntokun, A (ed), The Environmental Problems of the Niger Delta. Lagos: Friedrich Ebert Foundation. 192.

Ukaogo, Victor. (2007). 'The Paradox of Economic Transition and the Globalization of Poverty in Nigeria's Niger-Delta', Proceedings of the First International Conference on a Development Studies, March 13-16, Volume 1, No. 2, 10.

Ukaogo, Victor. (2008a). 'Resource Rights Agitations and 'New Forms of Conflict' in the Niger-Delta', Lagos Historical Review. Vol. 8. 91-112.

Ukaogo, Victor.(2008b). 'From Palm Oil to Crude Oil: The Impact of International Trade on Niger-Delta Communities', PhD Thesis submitted to the Post Graduate School, University of Lagos.

Ukaogo Victor. (2009). 'Strangulated Federalism', Resource Rights Agitations and the Deepening Crisis in the Niger- Delta', African Journal of History and Culture (AJHC) Vol. 1 (3), September, 44-053. 